\title{
An Immunofluorescence Study of Anti-pancreatic Islet Cell Antibodies in the Spontaneously Diabetic BB Wistar Rat
}

\author{
D. R. Pollard, K. Gupta, L. Mancino and I. Hynie \\ Bureau of Medical Biochemistry, Laboratory Centre for Disease Control, Health Protection Branch, Health and Welfare, Ottawa, Canada
}

\begin{abstract}
Summary. Sera from BB Wistar rats and Wistar control rats were evaluated for the presence of islet cell antibodies in a prospective study using an indirect immunofluorescence assay on pancreatic islet cell suspensions from cultured rat islets. Islet cell surface antibodies were detected in sera from all animals of the spontaneously diabetic BB Wistar rat colony. The antibody could be detected well before the clinical onset
\end{abstract}

of the disease and was present throughout the course of study of all diabetic animals. Sera from control Wistar rats were negative when tested for this antibody.

Key words: Islet cell surface antibody, BB rat, immunofluorescence, islet culture, cell suspension, pre-diabetes.
A number of investigators have reported antibodies in the sera of patients with insulin-dependent diabetes [1-5]. These earlier studies tested a human serum reaction on frozen or fixed sections from blood group 0 cadaveric donor pancreases. This islet cell antibody is reported to bind cytoplasmic antigens only $[6,7]$, and is found in $60 \%-85 \%$ of newly diagnosed patients with insulin-dependent diabetes. The percentage of patients with detectable levels of circulating islet cell antibodies decreases with time [8].

More recently, an islet cell surface antibody has been detected in the sera of diabetic patients $[6,9]$. Islet cell surface antibody is detected in a majority of insulindependent diabetic patients $(>60 \%)$ and is reported to lyse $\beta$ cells specifically from newborn rat islets. However, islet cell surface antibody is not diagnostic of insulin-dependent diabetes as it is found also in a significant proportion of first degree relatives (25\%).

The spontaneously diabetic BB Wistar rat presents a syndrome with many analogies to the development and expression of insulin-dependent diabetes in man [10, 11]. We have been interested in it as a model for examining the role that antibodies to pancreatic islet cells might play in the aetiology of insulin-dependent diabetes, with particular reference to the questions: (1) does the diabetic rat have a circulating antibody specific for a pancreatic islet cell but not present in the normal rat? and (2) if so, does the presence of this antibody precede the onset of the disease? We report here the results of an immunofluorescence study aimed at answering these questions.

\section{Materials and Methods}

\section{Animals and Sera}

The $\mathrm{BB}$ rat is maintained in our laboratories as a random-bred, closed colony. Animals are kept in an air-conditioned room $\left(20^{\circ} \mathrm{C}, 50 \%\right.$ relative humidity) with a 12-h light/dark cycle, and fed Purina Lab Chow 5001 and water ad libitum. Urinary glucose levels are determined daily on all BB rats using the glucose enzymatic test strip (Tes-Tape, Eli Lilly, Toronto, Canada). Individual rats are classified as diabetic on the basis of a positive glycosuria and they are subsequently maintained on daily PZ1 insulin. At the time of this study the incidence of diabetes in the colony was $70 \%$ and the average age of onset 85 days.

Eleven diabetic BB rats from seven litters, all diagnosed as diabetic on the same day and aged 12-16 weeks, as well as 12 pre-diabetic $\mathrm{BB}$ rats aged 8-12 weeks were selected for study. These animals were bled at weekly intervals $(1.5 \mathrm{ml}$ whole blood removed from the jugular vein following light anaesthesia) starting $24 \mathrm{~h}$ after diagnosis of the overt syndrome in the diabetic group. Blood was allowed to clot overnight at $4{ }^{\circ} \mathrm{C}$ and serum removed, heat inactivated at $56^{\circ} \mathrm{C}$ for $30 \mathrm{~min}$ and stored at $-40^{\circ} \mathrm{C}$ until tested for auto-antibodies.

The control rats were from a random-bred, closed colony of Wistar rats derived from the parent BioBreeding colony which gave rise to the spontaneously diabetic $\mathrm{BB}$ rat, and which is maintained separately. We consider it to be the real control colony for the BB rat. It has $0 \%$ prevalence of spontaneous diabetes. Blood samples $(5 \mathrm{ml})$ were obtained from ten 12-week old male control rats on the same day that bleedings of the experimental animals were initiated. Blood and serum samples were handled as described above.

\section{Cell Suspensions}

Islet cells: Five to seven-day old neonatal rats from the control colony served as donors of pancreases for the cell suspensions. Pancreatic islets were isolated by a modification of the standard collagenase method $[12,13]$. Pancreases were isolated aseptically and placed in Hanks buffer (Gibco Laboratories, Grand Island, USA) at $4^{\circ} \mathrm{C}$. The tissue 
was transferred to $16 \times 125 \mathrm{~mm}$ pyrex culture tubes, washed twice in cold Hanks buffer with sedimentation at $1500 \mathrm{rev} / \mathrm{min}$ on an IEC clinical centrifuge (International Equipment Company, Needham, USA) and resuspended in Hanks-collagenase solution (Worthington Diagnostics, Freehold, USA), with collagenase at a final concentration of $1.5 \mathrm{mg} / \mathrm{ml}$. Digestion was carried out for $12-15 \mathrm{~min}$ at $37^{\circ} \mathrm{C}$ on a Burrell wrist-action shaker (Burrell Corporation, Pittsburgh, USA) and was arrested by the addition of Hanks buffer $\left(4^{\circ} \mathrm{C}\right)$ and sedimentation at $2200 \mathrm{rev} / \mathrm{min}$. Following two washes in Hanks buffer with sedimentation at unit gravity, the digest was suspended in $3 \mathrm{ml}$ FicollHypaque solution (Ficoll-400, Pharmacia Fine Chemicals, Uppsala, Sweden, 11.6\%; sodium hypaque, Winthrope, Aurora, Canada, $19.0 \%$ ) over which $2 \mathrm{ml}$ Hanks buffer was layered. This gradient was centrifuged for $10 \mathrm{~min}$ at $800 \mathrm{rev} / \mathrm{min}$ and the isolated pancreatic islets collected from the interphase.

The islets thus isolated were maintained in culture for a minimum of $24 \mathrm{~h}$ before use in the preparation of cell suspensions. The standard culture condition for the purified islets was medium-199 (Gibco Laboratories, Grand Island, USA) supplemented with 10\% fetal calf serum (Gibco Laboratories, Grand Island, USA), and glucose $(5.5 \mathrm{mmol} / \mathrm{l})$. In a standard run, pancreases were isolated from $48-60$ newborn rats and the resulting islets were cultured in four $60 \times 15 \mathrm{~mm}$ plastic culture dishes.

For the preparation of cell suspensions, the medium was removed from the culture dishes and the adhered islets were washed with $5 \mathrm{ml}$ of Swim's medium (Gibco Laboratories, Grand Island, USA) supplemented with bovine serum albumin $(1 \%)$; HEPES $(20 \mathrm{mmol} / \mathrm{l})$; EGTA $(1 \mathrm{mmol} / 1)$; and $\mathrm{NaHCO}_{3}(0.2 \%)$. The final $\mathrm{pH}$ was adjusted to 7.1. The wash medium was removed by aspiration and fresh Swim's medium $(2 \mathrm{ml})$ was added to each plate. The adhered islets were dislodged, removed to siliconized pyrex tubes $(16 \times 125 \mathrm{~mm})$ and washed twice in Swim's medium with sedimentation at $1100 \mathrm{rev} / \mathrm{min}$. The islets were resuspended in DNase (Calbiochem, LaJolla, USA) in Swim's medium at a final concentration of $0.02 \%$, and incubated for $80 \mathrm{~min}$ at $37^{\circ} \mathrm{C}$ in a shaking water bath. The cell suspension was washed twice at $800 \mathrm{rev} / \mathrm{min}$ for $5 \mathrm{~min}$ in Hanks buffer containing fetal calf serum $(2 \%)$ and HEPES $(20 \mathrm{mmol} / \mathrm{l})$ and resuspended in the same buffer $(200 \mu \mathrm{l})$. The cells were counted with a standard haemocytometer and viability measured by trypan blue (NCS Diagnostics, Mississauga, Canada) exclusion.

Spleen, thymus and fibroblast cells: Cell suspensions were prepared from spleen and thymus tissues as described by Ford [14]. Donor animals were from the control rat colony. Fibroblast cells were obtained from the digestion of pancreatic tissue from the control colony rats and subsequently maintained in tissue culture.

\section{Serum Adsorption}

Sera were adsorbed by incubation with equal volumes of packed cells from spleen or thymus at $26^{\circ} \mathrm{C}$ for $30 \mathrm{~min}$. Adsorptions with fibroblast cells were performed at $26^{\circ} \mathrm{C}$ for $30 \mathrm{~min}$ using $3 \times 10^{6}$ cells $100 \mu 1$ sera.

\section{Immunofluorescence}

Cell counts were adjusted to approximately $1 \times 10^{6} / \mathrm{ml}$ and aliquots $(70 \mu \mathrm{l})$ placed in disposable culture tubes $(12 \times 75 \mathrm{~mm})$. Test sera $(35 \mu 1)$ diluted in an appropriate volume of Hanks buffer were added to the tubes, which were then incubated for $30 \mathrm{~min}$ at $37^{\circ} \mathrm{C}$ with gentle agitation. The cells were washed twice with Hanks buffer containing fetal calf serum (2\%) and HEPES $(20 \mathrm{mmol} / \mathrm{l})$ and sedimented at $1100 \mathrm{rev} / \mathrm{min}$ for $5 \mathrm{~min}$. To the pellets, $50 \mathrm{ul}$ of a 1:20 dilution of fluoresceinated sheep anti-rat IgG (General Diagnostics, Scarborough, Canada) was added and the cells resuspended and incubated for $30 \mathrm{~min}$ at $37^{\circ} \mathrm{C}$ with gentle agitation. The cells were washed twice in the supplemented Hanks buffer and then sedimented (1100 rev/min). The pellet was resuspended and transferred to marked slides.

The slides were air-dried and a cover glass mounted using buffered glycerol. The slides were evaluated using a Zeiss photomicro-

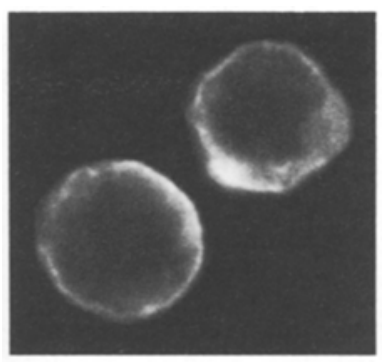

Fig. 1. Immunofluorescence of islet cell antibodies in rat pancreatic islet cells $(\times 600)$

Table 1. Summary of cellular immunofluorescence observed with rat sera

\begin{tabular}{lllllll}
\hline $\begin{array}{l}\text { Source of } \\
\text { serum }\end{array}$ & \multicolumn{5}{l}{ Serum dilutions } \\
\cline { 2 - 7 } & $1: 2$ & $1: 4$ & $1: 8$ & $1: 16$ & $1: 32$ & $1: 64$ \\
\hline $\begin{array}{l}\text { Diabetic rat } \\
\text { Control rat }\end{array}$ & +++ & +++ & ++ & ++ & + & $+/-$ \\
\hline & - & - & - & - & - & - \\
\hline
\end{tabular}

,,++++++ denote weak positive, positive, and strong positive membrane fluorescence. In all other tables + denotes a strong positive reaction for antibody

scope (Carl Zeiss, Oberkochen, FRG) equipped with an epi-fluorescence condenser and Zeiss filter combination 10 consisting of Schott filters, excitation BP $450-490 \mathrm{~nm}$, barrier BP $520-560 \mathrm{~nm}$. Scoring for a positive immunofluorescence was carried out by two observers independently on a 'blind' schedule.

\section{Results}

In a standard assay cultured islets were harvested from four plates and a cell suspension prepared. The recovery of cells and their viability was $1.01 \pm 0.39 \times 10^{6}$ and $95 \pm 3 \%$ respectively in ten different experiments (mean $\pm \mathrm{SD})$.

Cells showing an intense membrane fluorescence were observed following incubation with sera from diabetic animals (Fig. 1). Such cells were not observed following incubation with either sera from control rats or Hanks buffer alone. Table 1 shows the immunofluorescence score obtained using doubling dilutions of sera from four diabetic rats (taken $24 \mathrm{~h}$ after onset) and four control rats.

Two main points were apparent: (1) the immunofluorescence reaction titred as expected for a specific antigen-antibody reaction, and (2) not all cells of the cell suspension reacted with the positive sera. Since the reactions at both $1: 2$ and $1: 4$ serum dilution were scored +++ , a $1: 4$ serum dilution was employed in all subsequent tests. The percentage of cells demonstrating membrane fluorescence was $24 \pm 2 \%$ for ten diabetic rat sera, when a total field of approximately 200 cells per sera was examined. When sera from diabetic and control rats were adsorbed with either spleen, thymus or fibroblast cells and tested on islet cell suspensions, a positive fluorescence score was obtained in all cases for 
Table 2. Immunofluorescence testing of rat sera on cultured islet cells

\begin{tabular}{llc}
\hline Source of serum & \multicolumn{2}{l}{$\begin{array}{l}\text { Positive cell membrane } \\
\text { immunofluorescence }\end{array}$} \\
\cline { 2 - 3 } & Number & $(\%)$ \\
\hline Diabetic BB rat & $11 / 11$ & 100 \\
Pre-diabetic BB rat & $12 / 12$ & 100 \\
Control Wistar rat & $1 / 10$ & 10 \\
\hline
\end{tabular}

Table 3. Immunofluorescence detection of islet cell antibody in the spontaneously diabetic BB rat in relation to time of onset of diabetes

\begin{tabular}{|c|c|c|c|c|c|c|c|}
\hline \multirow[t]{2}{*}{ Rat Number } & \multicolumn{7}{|c|}{ Time-interval after onset of diabetes (weeks) } \\
\hline & Day 1 & 1 & 2 & 3 & 4 & 5 & 13 \\
\hline 43 & + & + & + & + & $t$ & + & + \\
\hline 44 & + & + & (died) & & & & \\
\hline 45 & + & + & + & + & + & + & + \\
\hline 46 & + & + & + & + & + & + & + \\
\hline 47 & + & + & + & + & + & + & + \\
\hline 48 & + & + & (died) & & & & \\
\hline 49 & + & + & + & (died) & & & \\
\hline 50 & + & + & + & + & + & + & + \\
\hline 51 & + & + & + & + & + & + & + \\
\hline 52 & + & + & + & + & + & + & + \\
\hline 53 & + & + & (died) & & & & \\
\hline
\end{tabular}

+ denotes detection of antibody

Table 4. Immunofluorescence detection of islet cell antibody in 8-12 week pre-diabetic BB rats in relation to time of onset of diabetes

\begin{tabular}{llllllll}
\hline Rat Number & \multicolumn{7}{c}{ Time-interval of blood sampling (weeks) } \\
\cline { 2 - 7 } & 0 & 1 & 2 & 3 & 4 & 5 & 6 \\
\hline 31 & - & - & + & + & + & {$[+]$} & + \\
32 & + & + & + & + & + & + & + \\
33 & + & + & {$[+]$} & + & + & + & + \\
34 & + & + & + & + & + & + & + \\
35 & + & + & + & + & + & {$[+]$} & + \\
36 & + & + & + & + & + & + & + \\
37 & + & + & + & + & + & + & {$[+]$} \\
38 & + & + & + & + & + & + & + \\
39 & + & + & + & + & + & {$[+]$} & + \\
40 & + & + & + & + & {$[+]$} & $($ died & \\
41 & + & + & {$[+]$} & + & + & + & + \\
42 & + & + & + & + & + & {$[+]$} & (died) \\
\hline
\end{tabular}

+ denotes detection of antibody: [ ] denotes onset of diabetes

the diabetic sera and the control sera gave negative reactions. Thus the antibodies we are detecting appear to be specific for islet cells.

Our main concern in this investigation was to characterize rats of the BB colony for the presence or $a b$ sence of antibodies in relation to onset of the diabetic syndrome. A summary of our immunofluorescence observations is presented in Table 2. Sera from all rats of the BB colony, whether overtly diabetic or pre-diabetic, gave a positive immunofluorescent reaction; whereas, virtually all sera from control Wistar rats were negative in the immunofluorescence assay. One rat (Wistar control 59) was assessed as weak-positive on a single test, but was negative in a second assay, All other control sera gave consistently negative results for antibody by this indirect immunofluorescence assay, individual sera being tested from two to eleven times.

Tables 3 and 4 show the time course of detection of a positive immunofluorescence reaction in relation to the onset of the disease in the spontaneously diabetic $\mathrm{BB}$ rat. Table 3 shows that all diabetic rats demonstrated the presence of antibody in sera collected 1 day post-diagnosis, and consistently showed a positive reaction at weekly bleedings up to 5 weeks post-detection. All sera remained positive at a 13 -week post-diagnosis bleeding.

The data on weekly bleedings of the pre-diabetic animals are shown in Table 4. The pre-diabetic animals were selected for study the day diabetes was diagnosed in our affected group, and were bled at the same time as the diabetic animals. Table 4 shows the relationship of the detection of anti-islet cell antibody and the diagnosis of overt diabetes in this experimental group. At the time of this study, the incidence of diabetes in our BB rat colony was $70 \%$. Eight of the $12(66 \%)$ selected prediabetic rats became overtly diabetic during the course of the study, which agrees well with the overall frequency in the main colony. All these animals showed a positive reaction for islet cell antibody well before onset of the disease. In the most extreme case (rat 37), a positive immunofluorescence reaction was detected 6 weeks before onset of the disease. Only rat 31 was negative initially and it developed a positive reaction 3 weeks before onset of the disease.

\section{Discussion}

These results show that by an indirect immunofluorescence assay an antibody or antibodies reactive with cells of a suspension prepared from cultured Wistar rat pancreatic islets can be demonstrated in the sera of all rats thus far tested from the spontaneously diabetic BB rat colony. The antibody is not detected in sera from rats of our control Wistar colony. The antibody is present for a considerable period of time both before and after onset of diabetes. In fact, four of our eight pre-diabetic animals did not become diabetic (rats 32, 34, 36 and 38, Table 4) yet consistently showed a positive antibody reaction; and the seven of our 11 diabetic rats, which lived $>13$ weeks following diabetes detection, were still positive for antibody during that period.

Some comments can be made about detection of anti-islet cell antibodies in the BB rat. Elder et al. [15] reported that the $\mathrm{BB}$ rat does not have pancreatic cell auto-antibodies. Tingle and Nakhooda (cited by Dyrberg et al.) [16] have been unable to demonstrate islet cell cytoplasmic antibodies by immunofluorescence on frozen sections of rat pancreas. The antibodies we are detecting are, we believe, the equivalent of the islet cell surface antibody associated with insulin-dependent dia- 
betes in man. Since the completion of our study, Dyrberg et al. [16] have reported an islet cell surface autoantibody in the BB Wistar rat using an ${ }^{125} \mathrm{I}$-protein A binding assay. Contrary to our findings, this method did not detect autoantibodies in the diabetes-prone animals.

One can only speculate on the significance of autoantibodies to the pancreatic islet cells in the pathogenesis of the diabetic syndrome in this animal model. Like et al. $[17,18]$ report that post-natal thymectomy, whole body irradiation or anti-lymphocyte antiserum can prevent clinical manifestation of the disease in the majority of the diabetic rats from the $\mathrm{BB} / \mathrm{W}$ colony. There is little doubt that an abnormal autoimmune response plays a key role in the development of the disease. However, it is impossible to decide, at this time, whether the circulating antibodies are the direct cause of the functional destruction of an islet cell, or whether they are only a secondary product of the abnormal immune state.

In this context, it would be even more speculative to try to draw a parallel to the human insulin-dependent diabetes. There is evidence for possible multiple causes in the human disease and probably only one of the human forms may be a direct analogy to the rat model. However, in view of the report that $25 \%$ of first degree relatives of insulin-dependent diabetic patients have circulating anti-islet cell surface antibodies [6], our consistent finding of similar antibodies in all diabetes-prone, non-diabetic BB rats may have added significance. It is conceivable that a relatively large number of people are affected by a condition which only in its most virulent form results in clinical diabetes, while in most others it is a self-limiting 'laboratory non-disease' manifested only by a 'biologically' non-significant increase of antipancreatic antibodies.

Acknowledgements. The authors are grateful to Mr. B. Thompson, Animal Resources Division for technical assistance and Mrs. Q. Gordon for typing the manuscript.

\section{References}

1. Irvine WJ, Gray RS, McCallum CJ (1976) Pancreatic islet-cell antibody as a marker for asymptomatic and latent diabetes and prediabetes. Lancet 2: 1097-1102

2. Lendrum R, Walker G, Cudworth AG, Theophanides C, Pyke DA, Bloom A, Gamble DR (1976) Islet-cell antibodies in diabetes mellitus. Lancet 2: 1273-1276

3. Doniach D, Bottazzo GF (1977) Autoimmunity and the endocrine pancreas. In: Joachim HL (ed) Pathobiology annual. AppletonCentury-Crofts, New York, pp 327-346

4. Del Prete GF, Betterle C, Padovan D, Erle G, Toffolo A, Bersahi
G (1977) Incidence and significance of islet-cell autoantibodies in different types of diabetes mellitus. Diabetes 26: 909-915

5. Irvine WJ, McCallum CJ, Gray RS, Campbell GJ, Duncan LJP, Farquhar JW, Vaughan H, Morris PJ (1977) Pancreatic islet-cell antibodies in diabetes mellitus correlated with the duration and type of diabetes, coexistent autoimmune disease and HLA type. Diabetes 26: 138-147

6. Dobersen MJ, Scharff JE, Ginsberg-Fellner F, Notkins AL (1980) Cytotoxic autoantibodies to Beta cells in the serum of patients with insulin-dependent diabetes mellitus. N Engl J Med 303: 1493-1498

7. Irvine WJ (1980) Immunology aspects of diabetes mellitus: A review (including the salient points of the NDDG report on the classification of diabetes). In: Irvine WJ (ed) Immunology of diabetes. Teviot Scientific Publications, Edinburgh, pp 1-53

8. West R, Colle E, Belmonte MM, Tingle A, Guttmann R, Hynie I, Thomas D, Wilkins J, Poirier R, Crepeau MP (1981) Prospective study of insulin-dependent diabetes mellitus. Diabetes 30 : 584-589

9. Lernmark $\AA$, Freedman ZR, Hofmann C, Rubenstein AH, Steiner DF, Jackson RL, Winter RJ, Traisman HS (1978) Islet cell surface antibodies in juvenile diabetes mellitus. N Engl I Med 299: 375-380

10. Nakhooda AF, Like AA, Chappel CI, Murray FT, Marliss EB (1977) The spontaneously diabetic Wistar rat. Metabolic and morphologic studies. Diabetes 26: 100-112

11. Marliss EB, Nakhooda AF, Poussier P, Sima AAF (1982) The diabetic syndrome of the BB Wistar rat: Possible relevance to Type 1 (insulin-dependent) diabetes in man. Diabetologia 22:225-232

12. Scharp DW, Kemp C, Knight MJ, Bollinger WF, Lacey PE (1973) The use of Ficoll in the preparation of viable islets of Langerhans from the rat pancreas. Transplantation 16:686-688

13. Braaten JT, Jarlfors U, Smith DS, Mintz DH (1975) Purification of monolayer cell cultures of the endocrine pancreas. Tissue Cell 7: 747-762

14. Ford WL (1979) The preparation and labelling of lymphocytes. In: Weir DM (ed) Handbook of experimental immunology. Blackwell Scientific Publications, Oxford, pp 23.7-23.8

15. Elder M, MacLaren N, Riley W, McConnell T (1982) Gastric parietal cell and other autoantibodies in the $\mathrm{BB}$ rat. Diabetes 31 : 313-318

16. Dyrberg T, Nakhooda AF, Baekkeshov S, Lernmark $\AA$, Poussier $P$, Marliss EB (1982) Islet cell surface antibodies and lymphocyte antibodies in the spontaneously diabetic BB Wistar rat. Diabetes 31: $278-281$

17. Like AA, Kislauskis E, Williams RM, Rossini AA (1982) Neonatal thymectomy prevents spontaneous diabetes meilitus in the $\mathrm{BB} / \mathrm{W}$ rat. Science 216: 644-646

18. Like AA, Rossini AA, Guberski DL, Appel MC, Williams RM (1979) Spontaneous diabetes mellitus: Reversal and prevention in the $\mathrm{BB} / \mathrm{W}$ rat with antiserum to rat lymphocytes. Science 206 : $2421-2423$

Received: 5 October 1982

and in revised: 18 April 1983

Dr. D. R. Pollard

Bureau of Medical Biochemistry

Laboratory Centre for Disease Control

Health and Welfare Canada

Ottawa, Canada KlA OL2 